\title{
PDGFR Gene Amplification
}

National Cancer Institute

\section{Source}

National Cancer Institute. PDGFR Gene Amplification. NCI Thesaurus. Code C148404.

A molecular genetic abnormality indicating the presence of multiple copies of a PDGFR family gene. 